\title{
DO "DESCONTRUIR" PARA CONSTRUIR: TRANSFORMAÇÕES SOCIOAMBIENTAIS NO ENTORNO DA UHE DE BALBINA - PRESIDENTE FIGUEIREDO, AM, BRASIL.
}

\section{"Desconstruct to construct": socio-environmental transformation in surrounding Balbina Hydroeletric - Presidente Figueiredo, AM, Brazil.}

\author{
Rodrigo de Oliveira Félix \\ Doutorando em Ciências do Ambiente e Sustentabilidade na Amazônia (PPG-CASA), UFAM. \\ rodrigogeoam@gmail.com \\ Adorea Rebello Cunha Albuquerque \\ Professora Adjunta do Departamento de Geografia da Universidade Federal do Amazonas \\ adorea27@yahoo.com
}

\begin{abstract}
RESUMO: A busca por desenvolvimento econômico e energético levou o governo federal brasileiro, em pleno período de ditadura militar, a avançar para o norte do país, onde se constatou um relevante potencial hidroelétrico presente na região. A (UHE) de Balbina-AM representa uma das várias intervenções políticas organizadas e implementadas como promessas de progresso para a Amazônia. Tal construção foi concebida sob diversas problemáticas, muitas das quais questionáveis até os dias de hoje, isso porque ocorreram modificações sociais, ambientais e econômicas no entorno do reservatório construído. Nesta pesquisa realizou-se um estudo onde foi possível analisar as transformações ocorridas no entorno do Reservatório da Usina Hidrelétrica de Balbina, tendo por finalidade entender como se organiza o atual espaço geográfico. Para a pesquisa foi utilizado o método indutivo foi o de estudo de caso, usando como metodologia: as coletas de campo, imagens de satélite para elaboração de mapas, pesquisa bibliográfica e documental, além de visitas aos institutos que colaboraram com informações complementares. Através da pesquisa foi possível identificar as modificações na paisagem e o processo de desterritorialização dos Waimiri- atroaris ocasionados pela implementação do projeto da UHE de Balbina, além é claro no que diz respeito às novas formas de uso e ocupação do solo. Os resultados também demonstram que mesmo com os grandes impactos ocorridos pela construção e implantação da usina, a água do reservatório contribuiu para a formação de novas territorialidades ocasionando as transformações socioespaciais em seu entorno.
\end{abstract}

Palavras-Chave: Hidrelétrica de Balbina, Impactos; Transformações.

ABSTRACT: The search for energy and economic development, leave the brazilian federal government, in the middle of a military dictatorship, moving to the north of the country, where there was a relevant hydroelectric potential present in the region. The Balbina-AM represents one of several political interventions organized and implemented as promises of progress for the Amazon. This construction was conceived under various problems, many of which were questionable until the present day because social, environmental and economic changes occurred around the reservoir built. In this research was carried out a study where it was possible to demonstrate and to analyze the transformations occurred in the surroundings of the Reservoir of the Hydroelectric Plant of Balbina, with the purpose of understanding how the current geographical space is organized. For the research the inductive method using case study as 
DO "DESCONTRUIR" PARA CONSTRUIR:

TRANSFORMAÇÕES SOCIOAMBIENTAIS NO ENTORNO

DA UHE DE BALBINA - PRESIDENTE FIGUEIREDO, AM,

BRASIL.

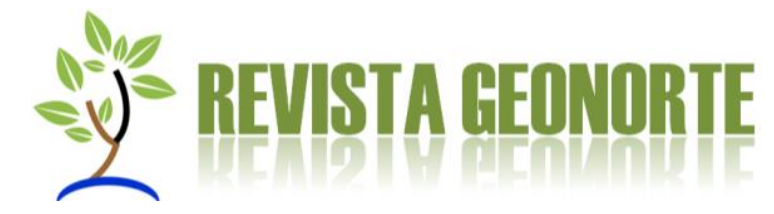

methodology: the field collections, satellite images for mapping, bibliographical and documentary research, as well as visits to the institutes that collaborated with complementary information. Through the research it was possible to identify the modifications in the landscape and the process of deterritorialization of the Waimiri-atroaris caused by the implementation of the Balbina HPP project, besides it is clear with respect to the new forms of use and occupation of the soil. The results also demonstrate that even with the large impacts that occurred due to the construction and implantation of the plant, the water of the reservoir contributed to the formation of new territorialities causing the socio-spatial transformations in its surroundings.

Key-Words: Balbina Hydroeletric; Impacts; Transformation.

\section{INTRODUÇÃO}

A segunda Revolução Industrial foi o marco inicial para o capitalismo e a produção das diversas formas de energia. $\mathrm{E}$, foi durante este período que o petróleo e a energia elétrica se tornaram forças motrizes de determinadas indústrias, bem como o aparecimento de indústrias petroquímicas que são grandes utilizadoras de petróleo como insumo (GUERRA, 1994).

O avanço na produção industrial e desenvolvimento tecnológico alavancado pelo governo brasileiro após a grande crise econômica de 1929 proporcionou ao país a partir da década de 1930 até 1980 melhorias significativas no que se refere ao seu desenvolvimento socioeconômico. Tais proposituras necessitavam de investimentos do governo, principalmente, no ramo energético e em todo o país (VEIGA e FONSECA, 2002).

Mas, somente a partir da década de 1950 com o governo de Juscelino Kubistchek é que ocorre um acelerado crescimento na economia e que por consequência priorizouse os projetos relacionados ao setor de energia elétrica, possibilitando a construção de várias usinas.

Com a criação das Centrais Hidrelétricas Brasileiras S.A. (Eletrobrás) em 1962, a situação energética mudou, pois, a mesma passou a controlar outras empresas do ramo energético no Brasil. Porém, neste período ainda não havia uma institucionalização e nenhuma organização padrão para que pudesse ocorrer um crescimento efetivo e funcional dentro deste setor. 
DO “DESCONTRUIR" PARA CONSTRUIR:

TRANSFORMAÇÕES SOCIOAMBIENTAIS NO ENTORNO

DA UHE DE BALBINA - PRESIDENTE FIGUEIREDO, AM,

BRASIL.

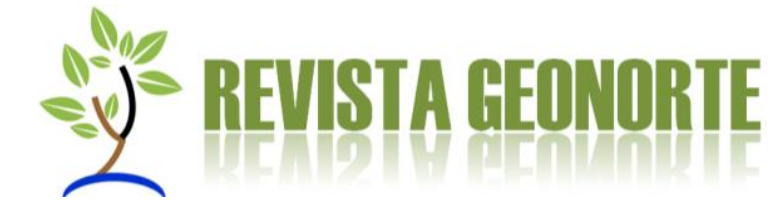

Em relação a outras regiões do Brasil, em 1968 o governo federal criou a ELETROSUL, geradora no sul do país e, em 1973, a ELETRONORTE, geradora no norte do país. Para consolidar o novo modelo estatal foi promulgada, em 1973, a Lei de Itaipu, que entre outras medidas criou a Itaipu Binacional, passando o controle desta e daquelas empresas para a Eletrobrás, e consolidando seu papel como agência de planejamento e financiamento federal no setor elétrico, atuando em todo o território nacional (CACHAPUZ, 2002).

Os estados possuíam suas empresas de distribuição e tinham seus próprios interesses e influência, muitas vezes contrários aos do Governo Federal, questionando, entre outras coisas, a equalização tarifária e o modelo institucional. A construção de Itaipu é desses exemplos, conforme testemunha Altino Ventura Filho': "A Eletrobrás construiu Itaipu com recursos próprios e investiu US\$ 12 bilhões. Foi impressionante! Não houve no mundo história parecida". Ao mesmo tempo, se inicia, também, o programa nuclear que indica qual o modelo de matriz energética proposta, à época para o Brasil.

Verifica- se, então, que era importante ao país expandir suas fronteiras dentro do seu território, pois, somente assim outras regiões poderiam contribuir para o desenvolvimento industrial e energético tão bem quisto e praticado nas Regiões Sul e Sudeste. O Norte e o Nordeste se tornaram viés para a criação de novas perspectivas de crescimento e emancipação do estado nacional em relação a outros países Sulamericanos.

Historicamente a produção de energia elétrica na Amazônia brasileira está ligada diretamente aos interesses inter-regionais e a política de integração energética do Governo Federal (BECKER, 2005).

Neste contexto, a Zona Franca de Manaus é instituída em 1967 em um momento em que o país enfrentava a ditadura militar, que justificou essa criação como sendo importante para o "povoamento da Amazônia" (SERÁFICO, 2005).

Discutindo o mesmo tema (SILVA, 1997) expressa que a criação da Zona Franca foi estimulada antes de 1964 e que teria como um dos seus principais "visionários" Daniel

\footnotetext{
${ }^{1}$ CMEB (Centro da Memória da Eletricidade no Brasil) Ciclo de palestras: a Eletrobrás e a história do setor de energia elétrica no Brasil. Rio de Janeiro, 1995b. ISBN 85-85147-33-4
} 
DO “DESCONTRUIR" PARA CONSTRUIR:

TRANSFORMAÇÕES SOCIOAMBIENTAIS NO ENTORNO

DA UHE DE BALBINA - PRESIDENTE FIGUEIREDO, AM,

BRASIL.

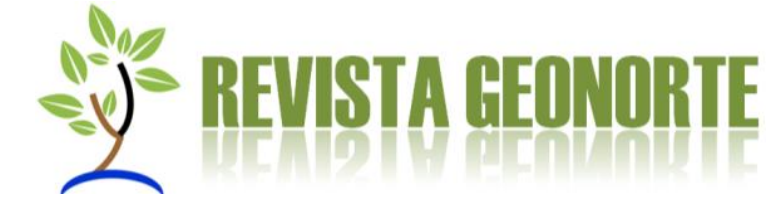

K. Ludwig e as suas convicções de trazer ao povo subdesenvolvido da região: a educação e que via grandes possibilidades no norte do país.

Esse desenvolvimento regional estava baseado em um tripé: $O$ Banco da Amazônia, a SUDAM e a Zona Franca de Manaus visto hoje como inadequado. A Zona Franca, que como descreve Corrêa (1997) "era um golpe mortal a possibilidade de afirmação de um capitalismo nacional independente; a economia "brasileira" já fora internacionalizada principalmente na esfera da produção industrial".

Em uma visão regionalista e antecedente a institucionalização da ZFM se verifica que as atividades econômicas do norte do país concentravam-se em Belém, na capital do Pará que de acordo com Bonfim e Botelho (2009, p.17) era a mais importante cidade da Amazônia naquele período. Tal era a sua importância dentro da economia, que 97,6\% dos investimentos incentivados da SUDAM na região eram voltados para ela.

Ainda citando Bonfim; Botelho (2009, p.18), Manaus tinha uma pequena representatividade comercial ligada à economia extrativa exportadora, onde eram praticados, principalmente, no interior do estado os produtos coletados e/ou extraídos eram: madeira em tora, borracha, sorva, castanha, pau rosa, cumaru, oleaginosas e etc.

Dessa forma, via-se a necessidade de investimentos na região e, principalmente, na cidade de Manaus que passou por diversas mudanças devido aos grandes projetos para o seu desenvolvimento. Muitas transformações ocorreram, entre elas, estão: a multiplicação dos habitantes, a influência da ZFM na renda per capita de Manaus, a demanda por serviços públicos e outros.

Para que a ZFM fosse colocada em prática foi necessário um pacto tripartite, que segundo Bonfim e Botelho (2009, p.20), foram realizados a partir de ações do Governo Federal, Governo Estadual e Prefeitura de Manaus. Onde cada participante ofereceria uma parcela de contribuição relativa ao conjunto de incentivos fiscais a projetos que se fixassem na capital amazonense.

Tais incentivos englobavam, principalmente, os impostos; um exemplo é o IPI (Imposto sobre Produtos Industrializados), o Imposto sobre Circulação de Mercadorias e Serviços (ICMS), e o Imposto sobre Serviços de Qualquer Natureza (ISS). Esses incentivos compensavam as desvantagens relacionadas à localização, que era considerada bem longínqua em relação aos grandes centros urbanos do país. 
DO “DESCONTRUIR" PARA CONSTRUIR:

TRANSFORMAÇÕES SOCIOAMBIENTAIS NO ENTORNO

DA UHE DE BALBINA - PRESIDENTE FIGUEIREDO, AM,

BRASIL.

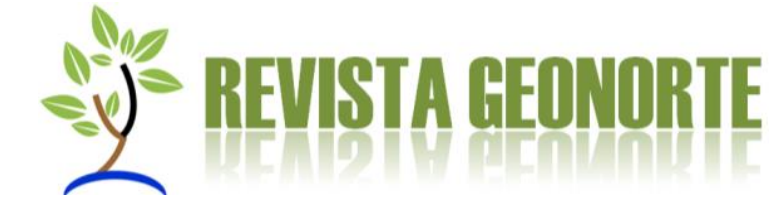

Quando ocorreu a implantação da ZFM, o seu espaço de delimitação correspondia a uma área de $10.000 \mathrm{~km}^{2}$. Dos polos previstos, industrial, comercial e agropecuário, o polo comercial foi o que se desenvolveu com mais rapidez.

A indústria, conforme Corrêa (1997, p. 52) foi sem dúvida o setor de maior absorção de mão de obra e, nessa fase considera-se que a implantação definitiva do Distrito Industrial deveu-se ao governo e suas cobranças sobre os empresários, em torno dos seus incentivos fiscais. As instalações se tornam definitivas, pois, há o processo de deslocamento da indústria e de matéria prima, além da diminuição do custo de produção e rápida modernização dos sistemas de transporte, de comunicação e infraestrutura.

Com a fixação do Polo Industrial de Manaus (PIM), ocorre o crescimento e expansão da área urbana e o movimento de populações. Conforme (PINTO, 1992, p. 131): "No estado do Amazonas, os deslocamentos de população se efetuam predominantemente em direção à cidade de Manaus, o que significa que não existe outro polo de atração importante, além, da capital".

Entende-se que as populações que migraram para a cidade de Manaus incrementaram a mão de obra já existente e contribuíram para o desenvolvimento socioeconômico da capital.

A expansão da cidade de Manaus, o aumento da densidade populacional e a efetiva implantação do PIM eram necessários às esferas dos governos federal e estadual investimentos no setor energético para a região, que fosse capaz de suprir as necessidades de energia, tanto para as cidades quanto para as respectivas indústrias instaladas no PIM (BONFIM e BOTELHO, 2009).

Entre os projetos voltados para a produção energética no norte do país, estava a Usina Hidrelétrica de Balbina - AM, que, especificamente, tinha como objetivo inicial de suprir a necessidade de energia da cidade de Manaus. Porém, antes da construção foram realizados estudos inerentes à viabilidade de produção de energia através dos rios da região.

Notadamente a partir dos anos 70 , intensificou-se o crescimento econômico, a integração e as mudanças nas estruturas, formas e funções da Amazônia. Esse processo de integração foi acompanhado por uma rápida modernização da economia regional, 
DO “DESCONTRUIR" PARA CONSTRUIR:

TRANSFORMAÇÕES SOCIOAMBIENTAIS NO ENTORNO

DA UHE DE BALBINA - PRESIDENTE FIGUEIREDO, AM,

BRASIL.

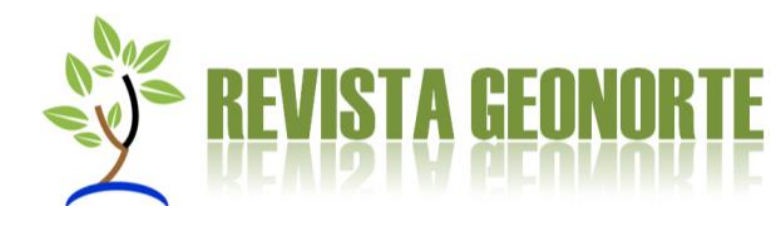

com destaque para as transformações na estrutura produtiva e no perfil das exportações. Tudo isso tinha que ter como base o também desenvolvimento da produção energética.

\section{MATERIAIS E MÉTODOS}

Nesta pesquisa realizou-se um estudo onde foi possível demonstrar e analisar as transformações ocorridas no entorno do Reservatório da Usina Hidrelétrica de Balbina, tendo por finalidade entender como se organiza o atual espaço geográfico. O método indutivo utilizado foi o de estudo de caso (YIN, 2015), com pesquisa causal de relação entre variáveis de fonte primária, combinado com o método dedutivo de pesquisa teórica e descritiva, tratando-se de variáveis de fonte secundária: as coletas de campo, imagens de satélite para elaboração de mapas, pesquisa bibliográfica e documental, além de visitas aos institutos que colaboraram com informações complementares.

\section{RESULTADOS E DISCUSSÕES}

\section{O HOMEM E A PAISAGEM: AS MODIFICAÇÕES AMBIENTAIS}

O projeto da usina hidrelétrica de Balbina se consolida no final da década de 1970 e a sua efetiva construção se inicia em maio de 1981 e finaliza em outubro de 1987. No entanto, a geração comercial de energia só começa em fevereiro de 1989, quando foram abertos os tapumes que barravam o rio, no distrito de Balbina, no município de Presidente Figueiredo - AM (ANEEL, 2006).

Neste processo de inundação se formou um reservatório de $2.560 \mathrm{~km}^{2} \mathrm{com}$ aproximadamente 3.300 ilhas. O enchimento do reservatório possibilitou a formação de uma área dendrítica ${ }^{2}$, devido ao relevo da região, o que proporcionou o aparecimento de grande quantidade de "paliteiros", ou chamado de cacaias (tronco de árvores mortas), pelos habitantes locais.

Fearnside (2008) relata que ficaram submersos cerca de 59 milhões $\mathrm{m}^{3}$ de cedro, angelim, andiroba, castanheira, jatobá e maçaranduba, dos quais, pelo menos, 9,3 milhões de $\mathrm{m}^{3}$ poderiam ter sido aproveitados para serraria, segundo inventário realizado à época pelo Instituto Nacional de Pesquisa da Amazônia (INPA).

${ }^{2}$ Formam um traçado de troncos que lembram os galhos da copa de uma árvore. 
DO “DESCONTRUIR" PARA CONSTRUIR:

TRANSFORMAÇÕES SOCIOAMBIENTAIS NO ENTORNO

DA UHE DE BALBINA - PRESIDENTE FIGUEIREDO, AM,

BRASIL.
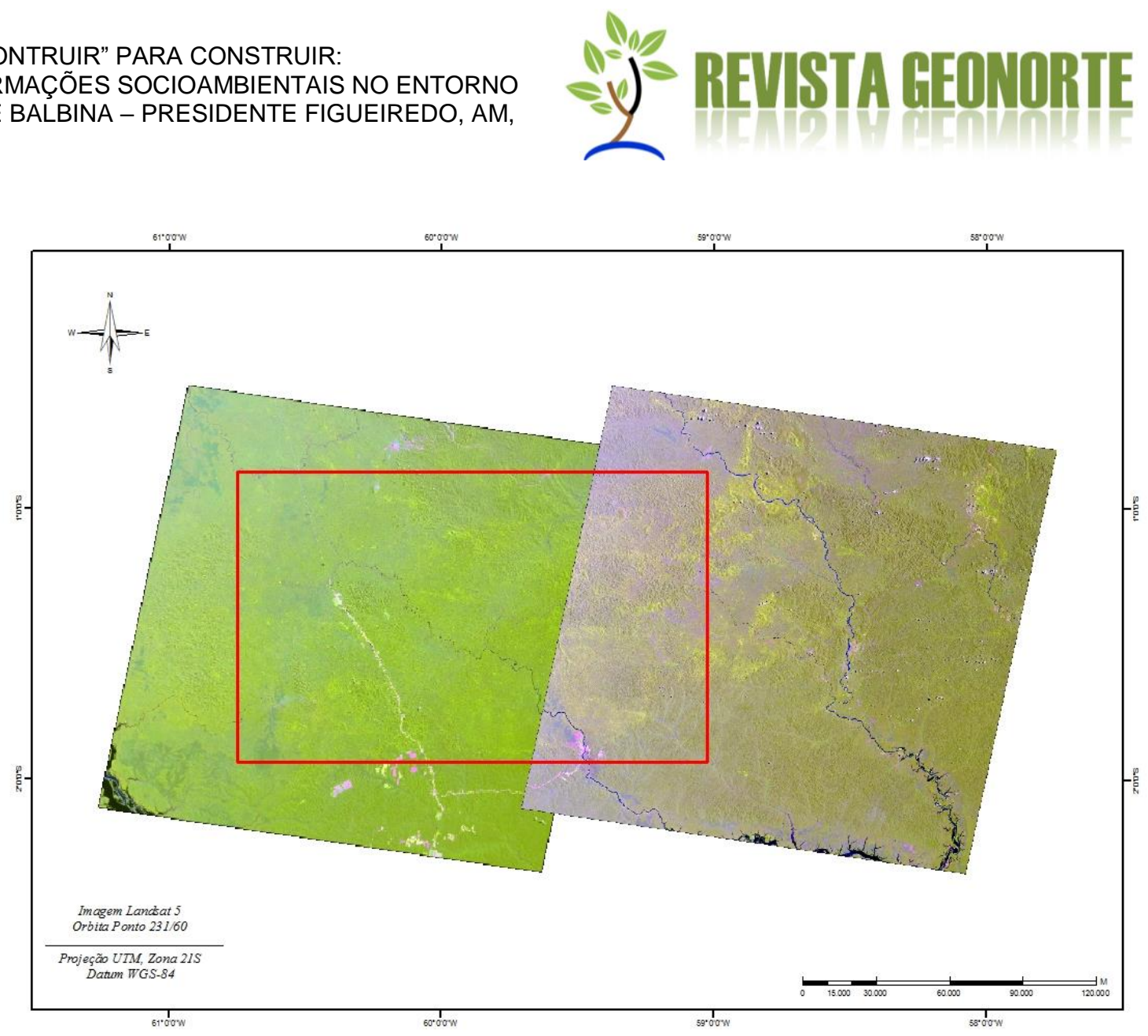

Figura 01.Rio Uatumã, antes da formação do reservatório. Elaborado por: Martha Benfica, 2016. 
DO "DESCONTRUIR" PARA CONSTRUIR:

TRANSFORMAÇÕES SOCIOAMBIENTAIS NO ENTORNO DA UHE DE BALBINA - PRESIDENTE FIGUEIREDO, AM, BRASIL.
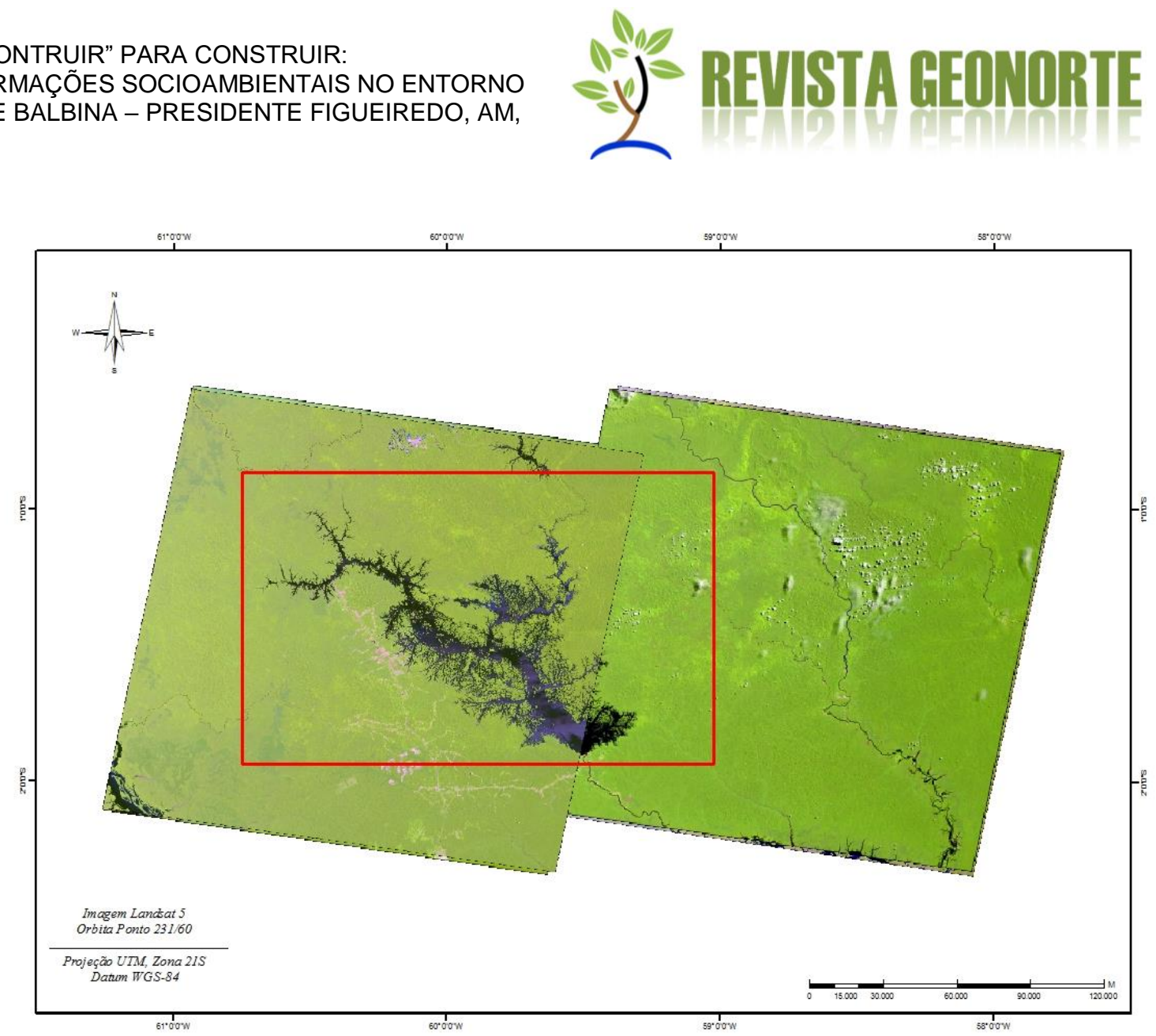

Figura 02. Rio Uatumã após a construção e implementação da usina de Balbina. Elaborado por: Martha Benfica, 2016.

As figuras 01 e 02 destacam a transformação ocorrida no espaço geográfico onde foi construída a usina hidrelétrica de Balbina, reconfigurando o entorno e formando um reservatório, mas, comumente chamado de "lago de Balbina" pelos comunitários.

$\mathrm{Na}$ área inundada ficaram extensões de floresta natural, que alagadas disponibilizaram matérias orgânicas e nutrientes ao corpo hídrico. As plantas que ficam submersas ao morrerem sofrem decomposição, liberam gás carbônico e metano (KEMENES, 2008; FEARNSIDE, 2008), mas, além destes, liberam, também, compostos orgânicos que se depositam no material em suspensão e no sedimento de fundo do reservatório.

Além da destruição das aldeias indígenas foram dizimados, também, os sítios arqueológicos que ali existiam (BAINES, 1992). Segundo, Bermann (2001), outro problema levantado seria a acidez da água, proveniente da decomposição da biomassa, principalmente, a madeira do tronco das árvores, que não foram retiradas a tempo. Essa acidez causaria a corrosão das turbinas e a poluição do lago a jusante do rio Uatumã, atingindo muitos ribeirinhos e a cidade de São Sebastião do Uatumã. 
DO "DESCONTRUIR" PARA CONSTRUIR:

TRANSFORMAÇÕES SOCIOAMBIENTAIS NO ENTORNO

DA UHE DE BALBINA - PRESIDENTE FIGUEIREDO, AM,

BRASIL.

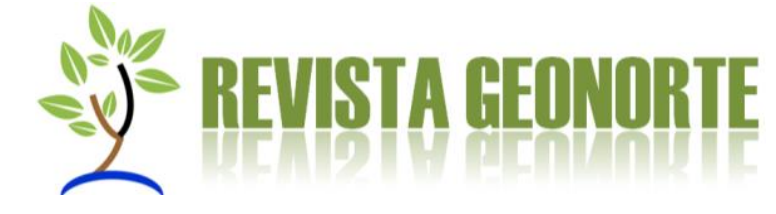

Dessa maneira, mesmo com os protestos contra a usina, que, aliás, foram rechaçados pelo governo por meio da Eletronorte - a construção e implementação se tornaram reais. As aldeias indígenas foram retiradas da área, a exploração da mina de cassiterita Pitinga, pela Mineração Taboca do grupo Paranapanema, também causou sérios problemas ambientais, poluição das águas do rio Abonari com a consequente diminuição dos peixes (BERMANN, 2001).

Mais de cem famílias de posseiros foram remanejadas da área do lago em troca de uma indenização da Eletronorte. Aqueles que permaneceram a jusante do rio Uatumã ou nas proximidades do lago enfrentaram sérios problemas com as águas insalubres dos poços perfurados pela Eletronorte, a poluição do rio Uatumã, a mortandade dos peixes e outras espécies animais que serviam de alimentação para a população ribeirinha.

\section{BALBINA E O POVO WAIMIRI-ATROARI}

O processo de represamento causou vários problemas ao meio ambiente da região, aos índios Waimiri- Atroaris que tiveram oito aldeias alagadas e as não tão numerosas famílias que ali viviam. Cientistas, ecologistas e populações da região tentaram impedir a construção da barragem e até o fechamento das comportas alegando a destruição de milhares de espécies de animais e vegetais, alguns deles ainda desconhecidos.

Segundo Thomé (1993), a tentativa de explorar as riquezas do território do povo Waimiri - Atroari não é recente. Com a implantação dos "Grandes projetos" na região, esta ambição tomou proporções de violência e dizimação desse povo, ou seja, esses povos já sofriam perseguição por suas terras antes mesmo do projeto da usina de Balbina e representavam um empecilho para as instituições governamentais e privadas.

Essa condição é observada em Santos e Nacke (1988):

Para o objetivo de integração nacional, justificativa dos "Grandes Projetos", da Amazônia, os povos indígenas representavam um obstáculo. Embora nunca se admita, de forma explícita, que um povo constitui empecilho, as políticas adotadas, mesmo pelos órgãos responsáveis pela política indigenista, sempre se orientaram no sentido de transformar os índios em não índios. (SANTOS E NACKE, 1988, p 77). 
DO “DESCONTRUIR" PARA CONSTRUIR: TRANSFORMAÇÕES SOCIOAMBIENTAIS NO ENTORNO DA UHE DE BALBINA - PRESIDENTE FIGUEIREDO, AM, BRASIL.

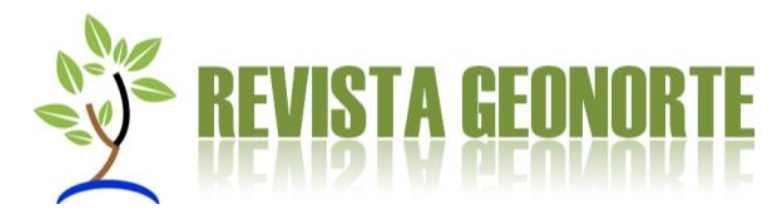

Nesse sentido, outros dois "Grandes Projetos" antecederam a UHE de Balbina nesse processo, a ponto de a hidrelétrica ter sofrido pouca resistência por parte de um povo, que já vinha lutando pela sua terra e sua sobrevivência.

Conforme Schwade (1985), desde tempos imemoriais, os Waimiri- atroari ocuparam o alto e médio rio Uatumã, como também os seus afluentes. Nos anos mais recentes utilizavam as bacias dos rios Jauaperi, Alalaú, Camanaú, Curiaú e o igarapé de Santo Antônio do Abonari como áreas mais específicas da pesca. No entanto, a área que ocupavam era restrita.

Sabe-se que embora as terras dos Waimiri-Atroari tenham sido alvo de cobiça por causa da coleta de goma não elástica e pau - rosa durante o período da borracha, sendo que os problemas se acentuaram, principalmente, com o advento do primeiro "Grande Projeto", no final dos anos 60: que foi a construção da BR 174, que liga Manaus a Caracaraí e Boa Vista (MACEDO, 2003).

À medida que as máquinas iam avançando na construção da estrada, a desterritorialização se configurava com a abertura de clareiras nas matas conforme mostra a figura 03 :

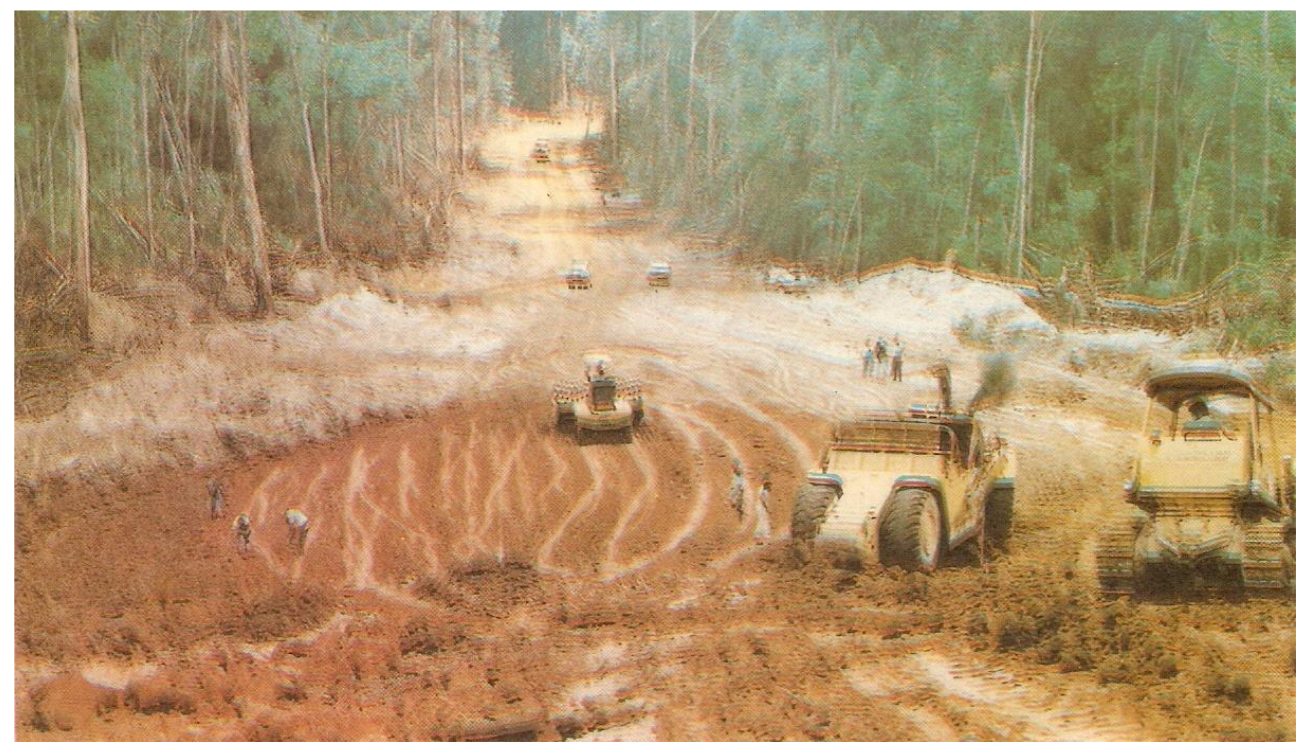

Figura 03. Abertura da BR - 174. Fonte - UHE Balbina - Memória Técnica (1997).

Essa estrada é construída com fins meramente estratégicos para o governo brasileiro, onde se enfoca o caráter econômico e militar. Em relação ao primeiro, a 
DO “DESCONTRUIR" PARA CONSTRUIR:

TRANSFORMAÇÕES SOCIOAMBIENTAIS NO ENTORNO

DA UHE DE BALBINA - PRESIDENTE FIGUEIREDO, AM,

BRASIL.

exploração de minérios e, por conseguinte, a única rota militar fronteiriça entre o Brasil e a Venezuela.

A construção da estrada atenderia, em princípio, o acordo firmado entre os países vizinhos, bem como diversos aspectos de interesse nacional, político, econômico e militar. No entanto, a rodovia teria que ser construída atravessando a selva amazônica, em uma região das mais "fechadas" e inóspitas, o que acarretaria em uma grande dificuldade para a sua implantação.

O traçado da estrada cortava boa parte do território cultural dos índios WaimiriAtroari, os quais eram conhecidos na região pela sua agressividade aos não índios e tidos como arredios a toda tentativa de contato (CARVALHO, 1982).

Diante disso, os indígenas representavam um grande obstáculo à concretização desse projeto. Dessa forma, o Departamento de Estradas de Rodagem (DER - AM) solicitou a intervenção da Fundação Nacional do Índio (FUNAI) para remover o empecilho.

O uso e a ocupação da terra constituem-se como elementos que permitem identificar a dinâmica econômica e social local, através da aquisição de informações sobre as atividades desenvolvidas sobre o espaço. Esse estudo é primordial no que se refere ao planejamento e na melhoria dos aspectos produtivos, o que tornam um suporte à sustentabilidade diante de questões ambientais, econômicas e sociais.

A realização de um diagnóstico do levantamento do uso e ocupação da terra no entorno da UHE de Balbina, permite avaliar as ações do ser humano sobre o ecossistema local, que por sinal, é frágil às mudanças no seu padrão e uso de ocupação. As informações sobre o uso da terra podem apresentar soluções para a gestão de problemas relacionados ao uso dos recursos naturais.

$\mathrm{Na}$ estrada de Balbina (AM -240) que liga a hidrelétrica de Balbina à BR-174 (Manaus- Caracaraí) já ocorreram vários conflitos no que tange o uso e a ocupação da terra, onde estavam envolvidos agricultores familiares, posseiros, fazendeiros e madeireiros da região. A figura 04 mostra a situação fundiária, ou seja, o uso da terra, as vias de entrada nas comunidades, a reserva biológica, terras do estado, da união e o reservatório da UHE de Balbina. 
DO “DESCONTRUIR" PARA CONSTRUIR:

TRANSFORMACÕES SOCIOAMBIENTAIS NO ENTORNO

DA UHE DE BALBINA - PRESIDENTE FIGUEIREDO, AM,

BRASIL.

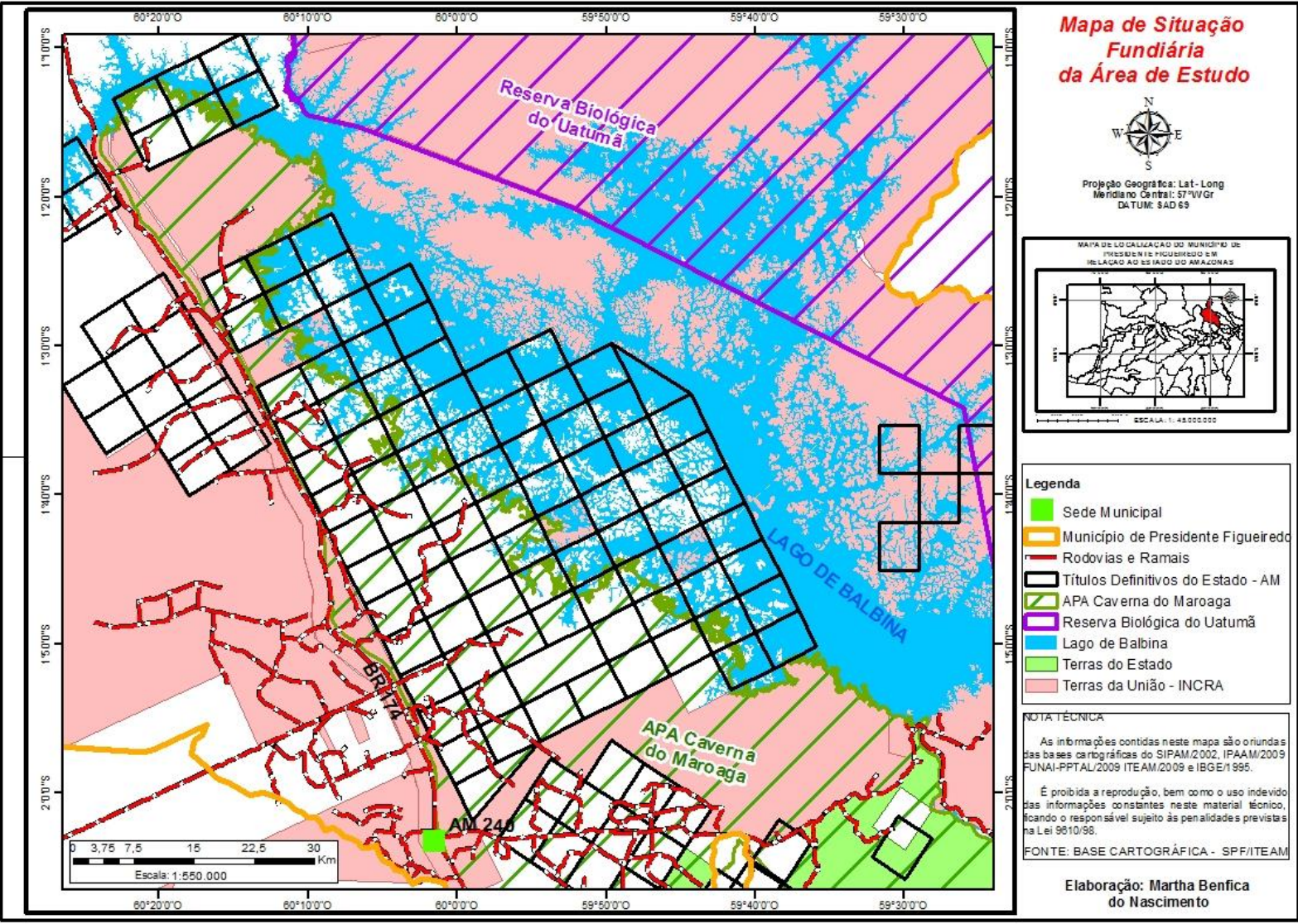

Figura 04. Mapa da situação fundiária da área de estudo.

Com todas essas irregularidades, cabe ao governo do estado junto à União questionar o domínio das terras tituladas irregularmente pelo governo do Amazonas. Não se pode admitir que os latifundiários se apropriassem de extensas áreas de terras com objetivo de obter uma indenização da União, em detrimento dos interesses coletivos prejudicando a reforma agrária do Estado.

\section{Uso da Terra}

Conforme mapeamento e a conseguinte pesquisa de campo o uso da terra pode ser dividido a partir de 4 classes que são: áreas antropofizadas, vegetação, hidrografia e ramais/rodovias. No primeiro momento se podem destacar as áreas 
DO "DESCONTRUIR" PARA CONSTRUIR:

TRANSFORMACÕES SOCIOAMBIENTAIS NO ENTORNO DA UHE DE BALBINA - PRESIDENTE FIGUEIREDO, AM, BRASIL.

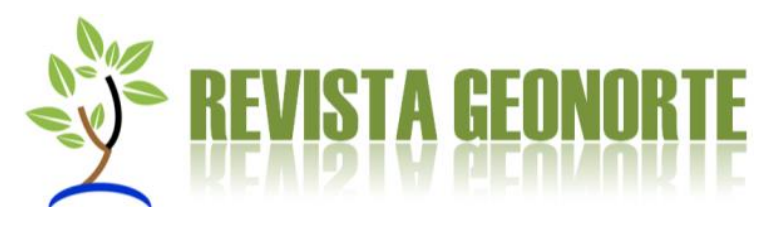

antropofizadas que podem ser definidas como: áreas agrícolas e não agrícolas. Abaixo, a figura 05 vai destacar a vegetação, hidrografia e áreas antropizadas.

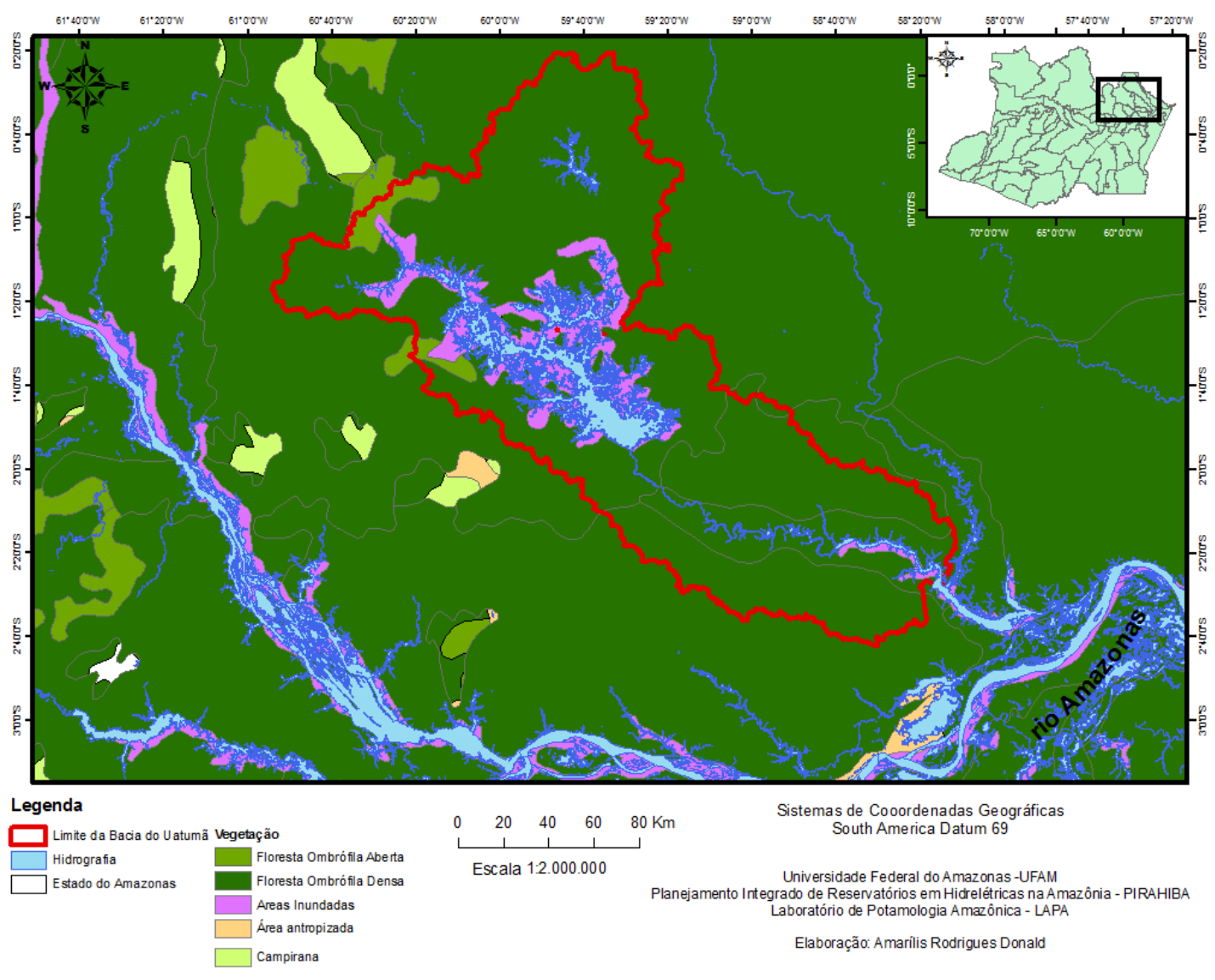

Figura 05: Mapa de uso da terra e vegetação.

\section{Áreas antropizadas - não agrícolas}

As áreas onde não ocorre produção agrícola tem maior importância econômica relacionada com as atividades de exploração mineral. Mesmo a área de estudo estando localizada próxima a uma zona de proteção ambiental, ela possui atividades de exploração mineral.

A principal atividade mineradora existente na região é a exploração da Brita. Essa atividade possui duas unidades de exploração: a primeira no ramal do Novo Rumo (Samaúma) e a outra entre os km 154 e 160 da BR-174 (Agroindústria - Martins LTDA). Onde na primeira, se encontra em funcionamento um britador com capacidade 
de $40 \mathrm{~m}^{3} / \mathrm{h}$ e na segunda com capacidade de $30 \mathrm{~m}^{3} / \mathrm{h}$. A produção está estimada em 8.000m3/mês de brita nas duas unidades de exploração (LIMA, p 68, 2015).

A produção gerada por essas duas unidades é utilizada na área de construção civil da região de Manaus. Essa produção chega até o comércio da capital do Amazonas através de transporte rodoviário que é realizado em carretas que usam a rodovia BR-174 para o seu escoamento. A comercialização dessa atividade econômica somente traz benefícios à população do entorno das unidades de exploração de forma indireta, através de compensações financeiras destinadas ao município.

Em geral a maior parte da área de pesquisa já foi ou é uma área de estudos relacionados à mineralogia. Sendo que em alguns casos foi realizada a prospecção de ouro, como por exemplo, no projeto estanho de Abonari, porém, a quantidade encontrada é considerada pequena o que não justifica a sua exploração.

Em estudos recentes, se pode responder que não existem registros de atividades de exploração aurífera dentro da região de pesquisa (CPRM,1998).

Na região concentrada ao sul da área de pesquisa não ocorreram registros de atividades de exploração mineral. Mas, de acordo com os registros do DNPM, já foram muitos os pedidos de licença em pesquisa mineralógica para a região de Balbina. Sendo o estudo da bauxita um dos maiores já existentes, no entanto não houve registro de quantidade necessária para a ocorrência de um interesse comercial.

\section{Áreas antropizadas - áreas agrícolas}

Durante pesquisa de campo e com o conseguinte mapeamento (figura 04), foi possível identificar áreas de pastagens, de lavouras temporárias e permanentes. No entanto, é importante ressaltar que, em virtude das limitações técnicas das imagens, não foi possível caracterizar espacialmente cada uma delas. No mapeamento das atividades de exploração e da escala empregada, as áreas correspondentes a esses anatropíssimos, não foram individualizadas espacialmente. 
As áreas agrícolas referentes às pastagens associam-se em grande parte, as pastagens cultivadas que já estão estabelecidas, por pequenos e médios produtores. O rebanho é composto por animais mestiços, o "gado branco", criados em regime extensivo nas ilhas próximas as margens do reservatório de Balbina, e intensivo pleno visando à produção de carne e leite.

As áreas relacionadas a esta categoria ocorrem, principalmente, ao longo das rodovias e ramais, com destaque para a maior concentração de empreendimentos agropecuários no norte da região de pesquisa e com menos intensidade na parte sul e central.

A pecuária também é praticada em muitas ilhas, na forma extensiva, onde, pequenos proprietários criam o gado como uma forma de complementar à sua atividade agrícola.

As áreas agrícolas referentes à agricultura temporária abrangem culturas de curta duração, ou seja, aquelas que duram menos de um ano desde a sua plantação até a sua colheita, e que necessitam geralmente de novo plantio após cada colheita. Já as áreas de agricultura permanente, compreendem espaços destinados a culturas de longa duração, que após a colheita não necessitam de novo plantio, produzindo então por vários anos consecutivos.

Dentro da área de estudos a região com maior desenvolvimento agrícola voltado para as culturas temporárias e permanentes está situada ao norte, especificamente nas ilhas. Na região da comunidade rumo certo a agricultura é praticada em maior escala. Essa região possui um maior número de comunidades e consequentemente um maior dinamismo socioeconômico.

Os produtos mais cultivados são aqueles referentes às lavouras permanentes como cupuaçu, goiaba, coco, limão, mamão entre outros. Já a agricultura temporária possui em seus períodos algumas representações com destaque econômico como: abóbora, melancia, pimenta cheirosa e etc. Na figura 06 se pode visualizar duas dessas culturas permanentes: 


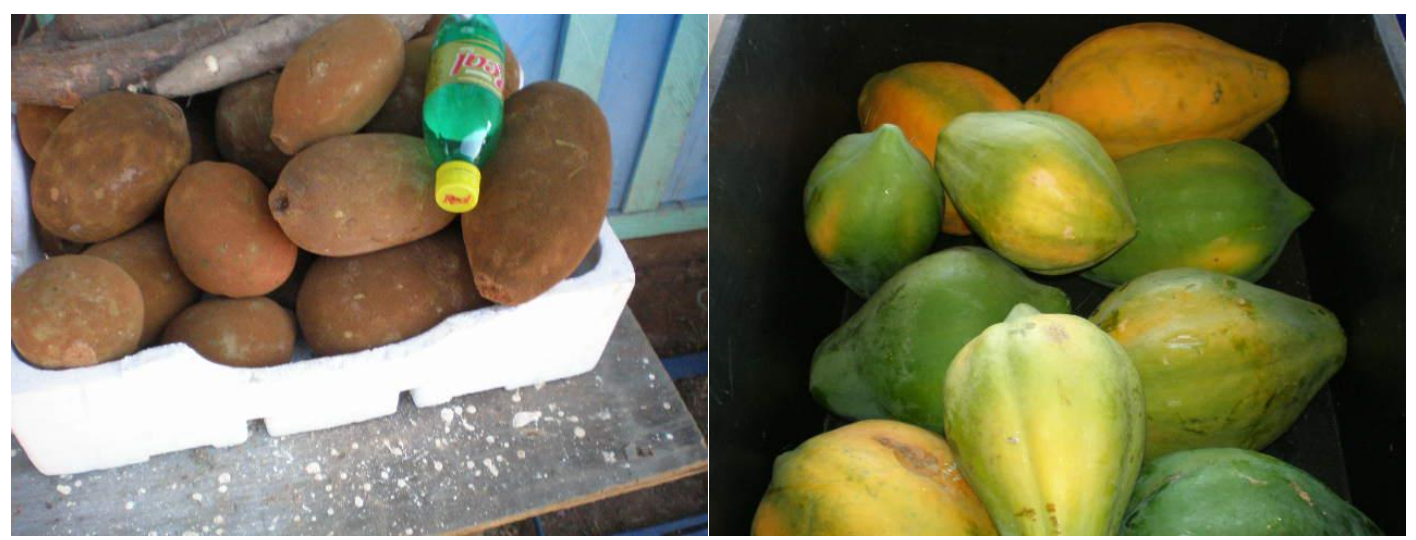

Figura 06. Lavouras permanentes. Fonte: Rodrigo Félix, 2015.

A figura mostra a presença do cupuaçu e do mamão como culturas representantes do tipo permanente. Elas são duas culturas com destaque de produção nesta região.

A agricultura temporária é representada pelas culturas da melancia e da pimenta cheirosa, a figura 07 mostra esse tipo de agricultura:

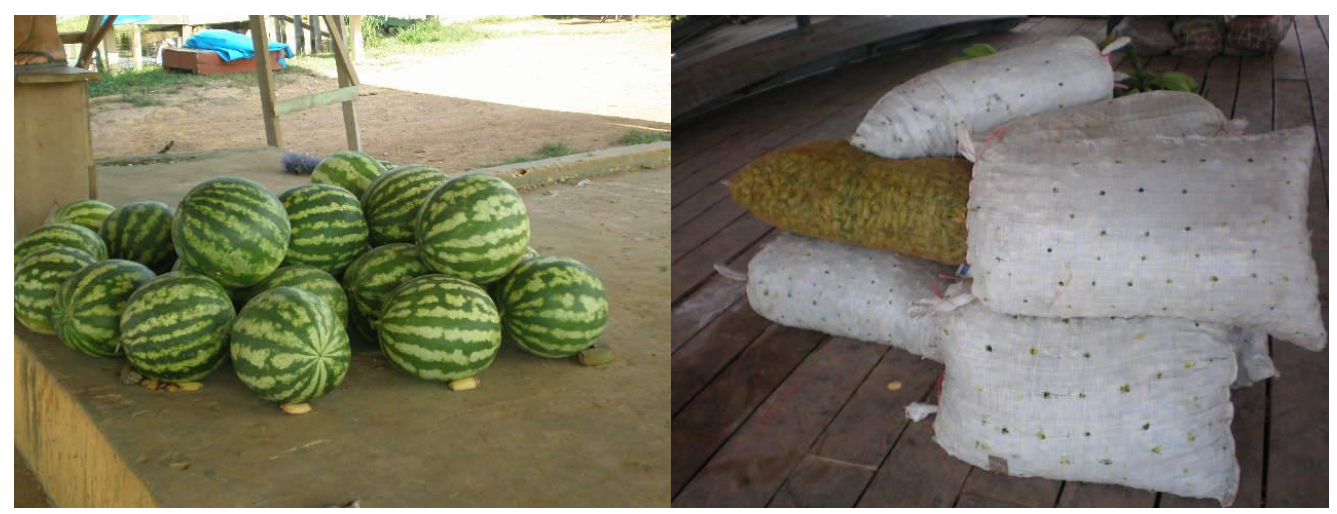

Figura 07. Culturas temporárias. Fonte: Rodrigo Félix, 2015.

Dentre os produtos produzidos a melancia e a pimenta de cheiro são dois produtos que contem uma boa aceitação comercial no mercado consumidor local e da cidade de Manaus, o que faz com que consequentemente os agricultores locais invistam nesse tipo de produção.

Tanto na agricultura permanente quanto na temporária, o comércio desses produtos representa uma grande importância na economia local. Visto que uma forma 
complementa a outra, pois, quando alguns produtos da agricultura permanente estão em baixa no seu comércio, outras culturas da temporária estão em plena produção e comercialização.

Constata-se que na região das ilhas e nas proximidades das comunidades Rumo Certo e Novo Rumo, onde a agricultura é muito diversificada, não só pelo fato das culturas temporárias e permanentes, mas sim, porque existe o cultivo de inúmeros produtos. A região apresenta uma relevante e variada produtividade.

Os produtos com maior destaque na comercialização são a macaxeira, a banana, o tucumã, o coco verde, além do limão. Sendo que esta produção serve para o abastecimento local e, ainda, são comercializados em outras partes do município de Presidente Figueiredo, em Iranduba e até para a cidade de Manaus.

Esses produtos chegam aos mercados consumidores, principalmente, por meio da secretaria municipal de desenvolvimento e abastecimento agrícola de Presidente Figueiredo juntamente com a associação dos produtores rurais. Alguns produtos, no entanto, são subsidiados pela CONAB que compra dos produtores e os coloca a disposição de mercados consumidores. Já em outros casos, a associação dos produtores negocia com outros parceiros comerciais.

Deste modo, a agricultura constitui a atividade produtiva que contem maior rentabilidade para as populações menos favorecidas da região do reservatório de Balbina. Dessa forma, se percebe a importância da água do reservatório para os atuais moradores do entorno, pois, a mesma possibilita tanto a produção agrícola como a pesca, diminui as distâncias entre as ilhas e as comunidades na margem esquerda entre outros fatores.

\section{Vegetação Natural}

A vegetação natural ainda constitui uma grande parte da área pesquisada, onde se predomina a floresta equatorial densa. A vegetação é explorada em alguns casos, sem um controle ou de uma forma que não seja sustentável. Se pode perceber pela figura que já existem espaços com grande incidência de desmatamento. 
Verifica-se que a área representa elevado grau de processo de desmatamento. Sendo este provocado pela derrubada da floresta para dar lugar a pastos ou para a retirada de madeira de lei. Dentro dessa área ainda apresenta uma maior concentração de pessoas, isso se deve à existência de um maior número de comunidades presentes ali devido a sua relação com a água.

A exploração dos recursos naturais é uma atividade complicada de ser mensurada economicamente, sendo que muitas das formas de aproveitar a floresta são realizadas de forma clandestina.

\section{Hidrografia}

A hidrografia da área de estudo representa uma porção das águas provenientes do rio Uatumã que devido ao represamento realizado para o funcionamento da usina teve como resultado o reservatório de Balbina, que com sua área alagada proporcionou sem nenhum propósito a utilização do mesmo para diversas atividades, entre as principais estão: a pesca comercial, e o turismo, principalmente através da pesca esportiva, o transporte de pessoas e mercadorias entre ilhas e comunidades, além, da geração de energia.

O reservatório proporciona a pesca comercial, que é desenvolvida em grande escala, principalmente, pela colônia de pescadores da vila de Balbina. Onde, de acordo com informações da própria colônia de pescadores, na unidade da vila de Balbina são cadastrados 180 pescadores, já na unidade do Rumo Certo e Novo Rumo são apenas 42. Abaixo uma figura que representa a pesca comercial na região: 


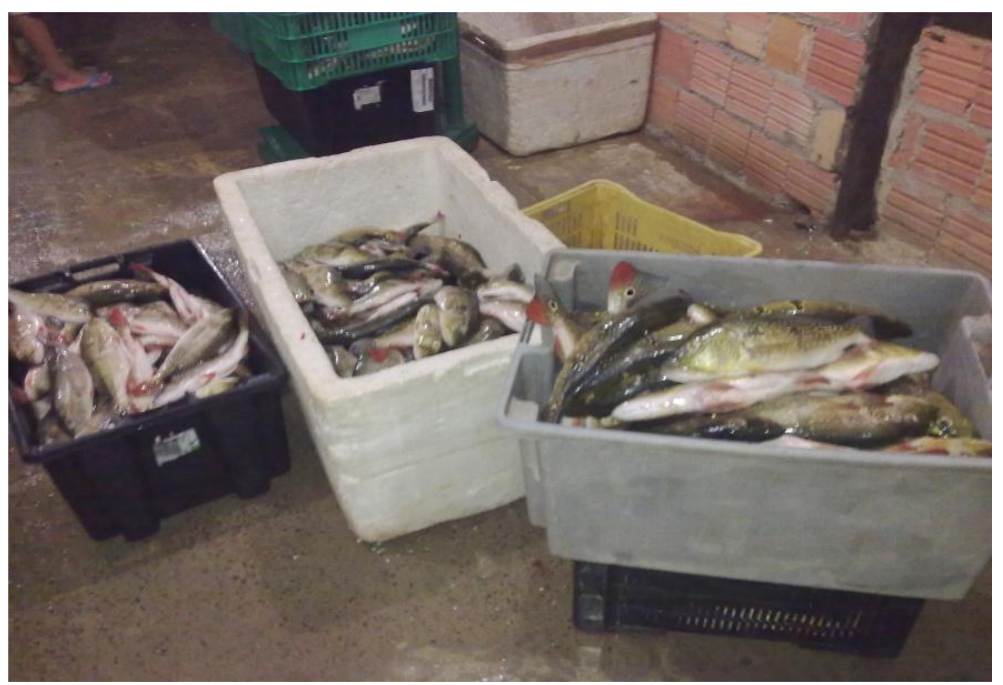

Figura 08. Tucunarés para a venda no galpão de atravessador. (Fonte: Ana Roberta Cañas, 2014).

Atualmente a pesca desenvolvida no reservatório está disciplinada de acordo com o (I.N n001/2014), este documento é o que regula a pesca dentro do reservatório da UHE de Balbina, tendo em vista as constantes pressões sobre o ecossistema aquático pela pesca desordenada ou sem o devido controle, principalmente, o do tucunaré (Cichla ssp) principal fonte de renda dos pescadores.

O acordo de pesca foi elaborado sob acordo de vários seguimentos sociais, entre eles a REBIO do Uatumã que tem com maior esforço para a concretização do documento entre todas as instituições. Este documento é considerado um marco na atividade pesqueira e na sustentabilidade do reservatório.

A pesca comercial no reservatório possui um grande potencial, pois, mensalmente é contabilizado, segundo a colônia de pescadores, um quantitativo entre 12.000 a $15.000 \mathrm{~kg}$ de peixes por mês, gerando uma economia entre $\mathrm{R} \$ 36.000 \mathrm{e}$ 45.000 (onde se considera o preço local de $\mathrm{R} \$ 3,00$ o kg).

Mesmo com o volume de pesca apresentado com elevados valores de renda que essa atividade traz, a pesca possui alguns entraves que dificultam a funcionalidade da mesma. Entre elas estão: a falta de união entre os membros associados, a falta de maior incentivo e apoio por parte das instituições do poder 
público, a irregularidade nos preços praticados, a falta de estrutura e parceiros comerciais.

Uma atividade que também ganhou destaque com a formação do reservatório de Balbina foi o turismo, principalmente ligado à pesca esportiva. Sendo que esta atividade possui um importante papel na economia da região, pois, a mesma se utiliza de mão de obra local.

Uma das possibilidades para diminuição de conflitos nessa região no que se relaciona a pesca dar-se-ia com a melhoria das ações do poder público no local, além da união dos associados e pescadores em geral na busca de seus respectivos ideais.

Anualmente, é realizado um torneio de pesca na área do reservatório o que contribui e é importante para a dinâmica da economia local, pois, aumenta o fluxo de turistas e, consequentemente, um maior volume de divisas para a região. Tal evento é realizado através das parcerias entre a secretaria de meio ambiente e sustentabilidade, secretaria de cultura de Presidente Figueiredo, REBIO -Uatumã e lideranças locais.

No reservatório, o turismo está em função da pesca esportiva, pois, ela traz o lazer e diversão. Na área de pesquisa identificou-se que a pesca esportiva é o principal elemento atrativo ao turismo. Nesta área já existe uma boa infraestrutura de apoio aos turistas que se interessam em conhecer as belezas locais, e também a prática da pesca esportiva.

Portanto, o turismo na área da pesquisa tem um grande potencial a ser explorado. Assim, existe a então necessidade de melhoria no que se refere a divulgação de potencial, para se tornar um empreendimento ainda mais rentável para as populações locais e empreendedores em geral.

\section{Ramais e Rodovias}

As vias terrestres utilizadas para se ter acesso ao reservatório e as comunidades do entorno são formadas pela rodovia federal BR- 174 (Manaus - Boa 
Vista), e estadual a AM - 240 e algumas municipais chamadas de vicinais ou popularmente chamadas de ramais.

A rodovia federal BR-174, é uma longitudinal (norte-sul), e liga a cidade de Manaus (AM) à capital Boa Vista (RR). Sendo esta rodovia um importante eixo de ligação com outras vias na região ao norte do reservatório de Balbina. Ela permite a integração com a zona de maior progresso econômico da área de estudo, a comunidade Novo Rumo e as ilhas nas proximidades desta comunidade.

Já a rodovia estadual AM -240 se constituem como único acesso por via terrestre à UHE de Balbina. Foi construída acompanhando o divisor de águas das bacias dos rios Uatumã e Urubu. A rodovia permite a interligação com toda a parte sul da área de influência do reservatório, e ainda, desempenha um importante papel na economia da região, pois, através dela se escoa a maior parte da produção pesqueira, além do fluxo de turistas que utilizam a via para se ter acesso ao reservatório.

Os ramais que interligam as comunidades as vias federal e estadual são de pequena extensão, essas estradas são vicinais, normalmente, com qualidade precária, porém, mesmo no período de intensas chuvas na região, elas proporcionam um razoável tráfego para os veículos de pequeno e médio porte.

A importância dos ramais para as comunidades, principalmente, para aquelas onde existe maior produção agrícola, pois são vias de ligação entre a estrada principal (BR-174 e AM -240). No caso dos ramais Rumo Certo e Novo Rumo elas são eixos de ligação entre as produções provenientes das ilhas por via fluvial, que ao chegarem às comunidades, essa produção passa pelos ramais para então conseguir escoar pela BR-174, permitindo e facilitando esse fluxo de mercadorias e pessoas.

As vias fluviais na parte sul da região são formadas ao longo do reservatório e no rio Uatumã, a jusante da barragem. Elas são utilizadas principalmente por pescadores e como rotas para passeios turísticos. Já as vias fluviais da parte norte do reservatório formam um conjunto de acessos de diferentes partes do reservatório, uma vez que existe uma grande quantidade de pessoas que habitam as ilhas (cacaias), e necessitam se deslocar. 
As vias fluviais detém uma grande importância em toda a área de influência do reservatório, pois, estão servindo de apoio ao turismo, à pesca, o escoamento da produção e a circulação de pessoas e mercadorias. No entanto, com toda a necessidade e importância das mesmas, elas precisam de um complemento para que todas as atividades possam se realizar. Sendo os portos a infraestrutura básica necessária para que esse fluxo melhore e se torne digno para os moradores.

Abaixo a figura mostra parte da via fluvial do reservatório que vai de encontro a ramal localizado na comunidade Boa União (Rumo Certo):

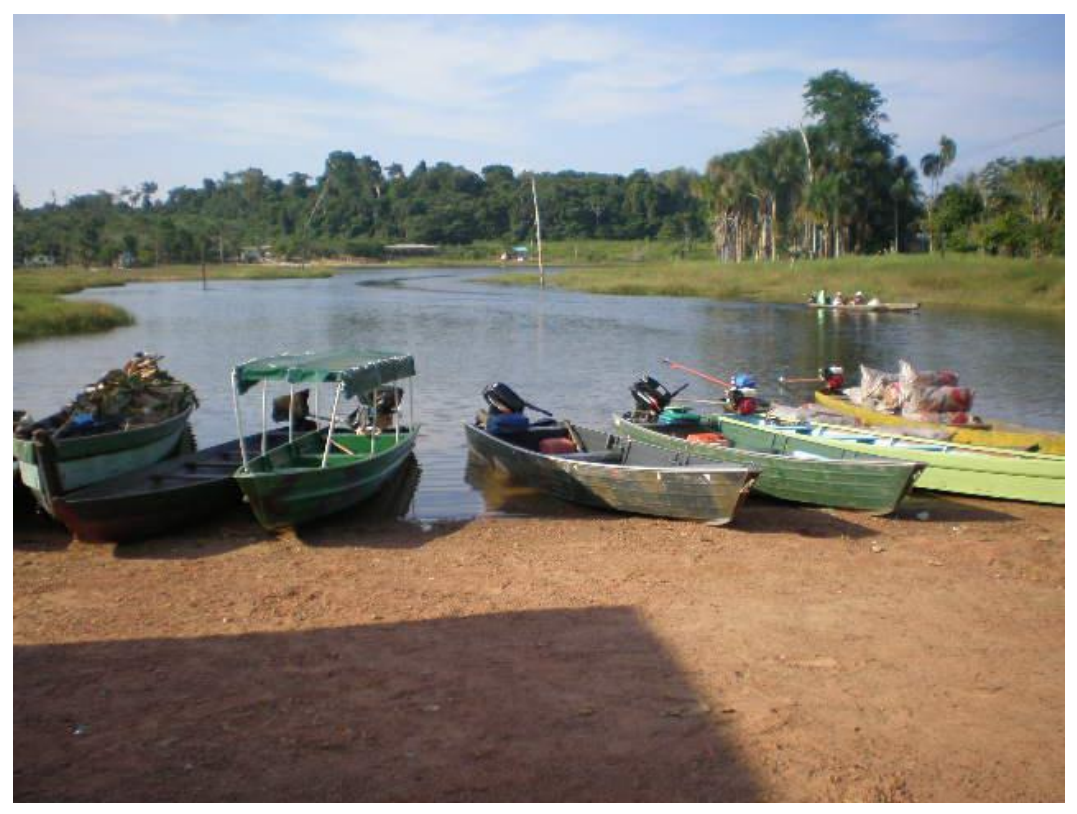

Figura 09. Saída do reservatório no encontro com o ramal. Fonte: Rodrigo Félix, 2015.

O porto do Rumo Certo é o mais amplo, onde se permite um maior fluxo de pessoas e de circulação de produtos de origem agrícola. A área no qual ele está localizado, possuí um expressivo contingente populacional, tanto no aglomerado rural, quanto disperso, nas ilhas. Dessa maneira, a necessidade de ir e vir e a prática do comércio são os maiores motivos no qual essa comunidade possui um espaço mais amplo. Abaixo se pode observar o espaço do porto da comunidade Rumo Certo: 


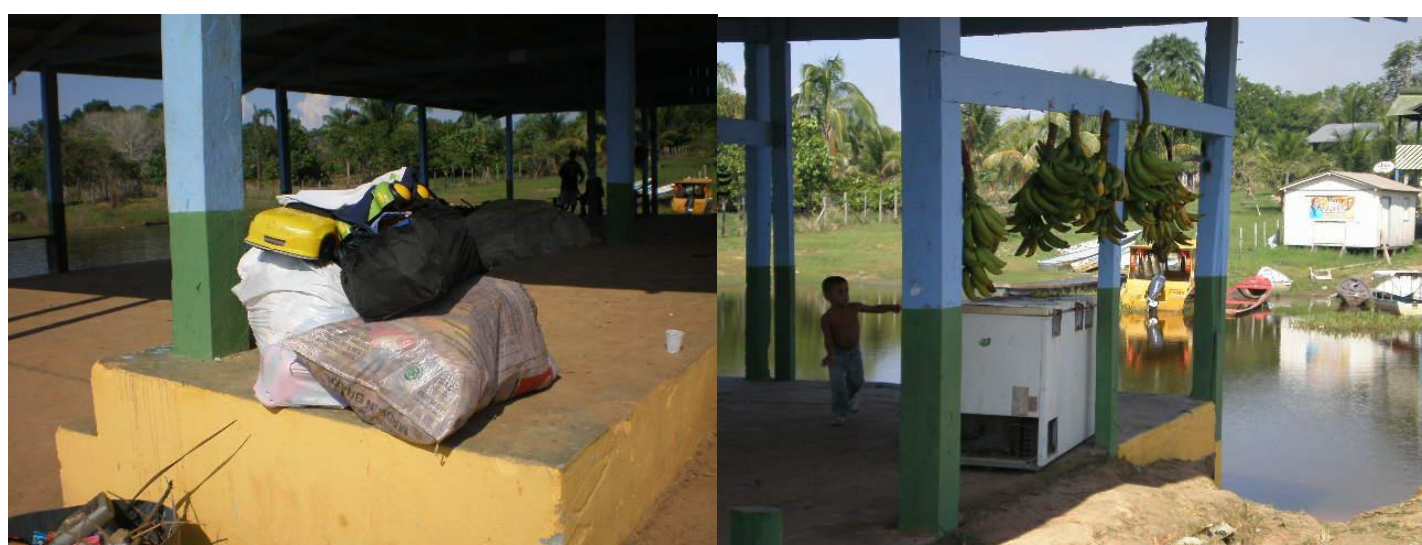

Figura 10. Porto da comunidade Rumo Certo. Fonte: Rodrigo Félix, 2015.

Nas proximidades da vila de Balbina, na parte sul do reservatório, tem o porto do "Mirandinha". Atualmente, ele é exclusividade para o apoio ao turismo, pois, permite o embarque e desembarque de turistas que entram no reservatório em busca da pesca esportiva ou de lazer.

Portanto, a melhoria no que se relaciona à infraestrutura das vias de transporte é condição fundamental para a dinâmica socioeconômica local. Haja vista que as vias de escoamento da produção local necessitam estar de acordo com as demandas e as possibilidades de crescimento dos fluxos do comércio. Seja na agricultura, na pesca ou mesmo na mineração, pois, a possibilidade de aumento dos fluxos comerciais da região são promissores e que os mesmos podem influenciar não só a estrutura econômica local, mas de outras regiões, inclusive da cidade de Manaus.

\section{CONSIDERAÇÕES FINAIS}

O processo histórico de construção da UHE de Balbina nos remete a um ideal de pensamento, onde fora construído em intensos períodos políticos e econômicos de nosso país. As ideias no que diz respeito a "Amazônia" eram muitas, mas, tal interesse do governo federal surge somente por causa da busca de desenvolvimento e controle do Estado nacional nesta região, que antes era vista como obsoleta e não tão benquista até determinado momento.

Os interesses pela região norte surgem a partir de um regime estratégico, que sempre buscou alternativas para a ampliação dos horizontes desenvolvimentistas, 
pois, a inflação populacional, a busca de novos mercados e espaços para o desenvolvimento do ramo energético de certa maneira obrigaram o governo a procurar alternativas econômicas em outras partes do país.

Entre os vários projetos de cunho energético voltado para a região norte do Brasil estava a Usina Hidrelétrica de Balbina, que inicialmente tinha como objetivo suprir a necessidade energética da população da cidade da capital e também da produção do Polo Industrial de Manaus.

Dentro deste contexto é que surge a ideia, e consequentemente, o planejamento para a construção de uma usina hidrelétrica próxima a Manaus, especificamente, na área da bacia do rio Uatumã e que sua produção de energia fosse eficaz ao ponto de suprir às necessidades no mínimo locais da demanda de energia. Muitos estudos e visitas foram realizados com um único propósito, que foi a aprovação deliberada para a construção da usina, mesmo sendo mesma a causa de muitas modificações estruturais e ambientais.

A construção da usina após sua aprovação se concebe a partir de muitas críticas, que advinham desde a inviabilidade econômica de tal obra, assim como os impactos sociais e ambientais provocados. Todo esse processo foi caracterizado por um desencontro de variadas informações.

Os impactos ambientais e sociais foram diversos desde o período de construção até o fechamento das comportas da usina em 1989. Entre os impactos ambientais se revelam o alagamento de quase $3 \mathrm{mil} \mathrm{Km}^{2}$ de floresta, onde ocorreu a mortandade de milhares de espécies de animais e vegetais, além é claro da presença de metano na água do reservatório devido a não retirada das árvores da respectiva área alagada.

Já os impactos sociais estão relacionados ao processo de desterritorialização e reterritorialização dos indígenas Waimiri-atroari que habitavam grande parte da região do rio Uatumã. Tal situação afetou o modo de vivência social e cultural desses povos, o que configurou mudanças espaço-temporais relevantes para essas populações até os dias atuais. 
Algumas medidas foram tomadas como formas de "compensar" os efeitos e impactos causados pela construção e consequente implementação da usina. Dentre essas proposições que se realizaram estão: a ReBio Uatumã, a Terra Indígena Waimiri-Atroari e a Área de Proteção Ambiental (APA) Caverna do Maroaga.

Para melhor entender e analisar essas modificações ocorridas no entorno do reservatório de Balbina, essa pesquisa se pautou em procurar compreender as transformações socioespaciais que culminaram em novas formas de espacialização, uso e ocupação do solo e a inter-relação do homem com a água.

Através da pesquisa foi possível perceber que com a construção da UHE de Balbina e o alagamento de uma grande área de floresta que encobriu uma significativa porção de terra, que devido as diferenças de declividade, acabaram resultando em diversas ilhas, aproximadamente, 3 mil delas dentro do reservatório da usina hidrelétrica.

Além das ilhas, a formação de novas territorialidades na margem esquerda do reservatório, por meio da criação de comunidades em toda essa extensão, praticamente, só se tornou possível com o aumento populacional nessa região devido à presença da água, que se tornou o elemento principal e primordial para a vida das populações que hoje lá vivem.

Sendo assim, compreende-se que ocorreram muitas modificações ambientais e sociais no entorno do reservatório, que além da água, o uso e ocupação do solo representam uma das principais formas de construção das territorialidades que se formaram com o passar dos anos.

Portanto, a falta de entendimento sobre a realidade local, tanto no que se refere aos aspectos sociais, econômicos e naturais não foram analisados no período de planejamento, construção e implementação da usina, sendo deixados de lado. Dessa maneira, as ações centralizadas e indiscriminadas não proporcionaram à participação popular ao processo de decisão na implantação da UHE de Balbina.

Dessa forma, compreender as novas espacialidades presentes naquele território é essencial para a produção de ações que visem conhecer e melhorar a vida das populações locais, pois, os impactos ambientais e sociais são irreversíveis e 
irrefutáveis. No entanto, se deve entender que nos dias atuais existe uma realidade socioespacial no entorno do reservatório que não pode ser excluída, e que as tomadas de decisões que envolvam a água e o uso e ocupação da terra devem ser pautadas nessa atual reconfiguração.

\section{REFERÊNCIAS}

ANEEL - Agência Nacional de Energia Elétrica (2006): Sistema de Informações Georreferenciadas do Setor Elétrico. Disponível em: <http://sigel.aneel.gov.br/>. acesso em:05 set. 2006 .

BAINES, Stephen G. (1992). A Política Indigenista Governamental e os WaimiriAtroari: Administrações Indigenistas, Mineração de Estanho e a Construção de “Autodeterminação Indígena” Dirigida. Série Antropologia no 126, UNB, Brasília.

BECKER, B. Porque não perderemos a soberania sobre a Amazônia? In: ALBUQUERQUE, S (org). Que país é esse? Pensando o contemporâneo. Globo, São Paulo, 2005.

BERMANN, Célio (2001). Hidrelétricas no Brasil: Desafios e Perspectivas. Revista Tempo e Presença nº 317, maio-junho/2001, Editora Koinonia, Rio de Janeiro.

BONFIM, R; BOTELHO, L. Zona Franca de Manaus - Condicionantes do futuro. Manaus: Editora Valer, 2009.

CACHAPUZ, Paulo Brandi de Barros (Coord.). O planejamento da expansão do setor de energia elétrica: a atuação da Eletrobrás e do Grupo Coordenador do Planejamento dos Sistemas Elétricos. Rio de Janeiro: Centro da Memória da Eletricidade no Brasil, 2002.

CARVALHO, J, P, F. Waimiri- Atroari: A história que ainda não foi contada. Brasília. 1982.

CMEB (Centro da Memória da Eletricidade no Brasil) Ciclo de palestras: a Eletrobrás e a história do setor de energia elétrica no Brasil. Rio de Janeiro, 1995b. ISBN 85-85147-33-4.

EMBRAPA. Boletim agrometeorológico. EMBRAPA/CPAA, Manaus. 23 p. 1998.

FEARNSIDE, Philip M. A Hidrelétrica de Balbina: o faraonismo irreversível versus o meio ambiente na Amazônia / Philip M. Feamside. -- Sio Paulo: Instituto de Antropologia e Meio Ambiente, 1990. -- (Estudoe IAMA; 1) 
FEARNSIDE, Philip M.. Hidrelétricas como "fábricas de metano": o papel dos reservatórios em áreas de floresta tropical na emissão de gases de efeito estufa. Oecol, 2008.

GUERRA, Oswaldo Ferreira. Estudo da competitividade da indústria brasileira. In: Nota Técnica Setorial do Complexo Químico. Campinas: Unicamp, 1994.

KEMENES, A; FORSBERG, B; MELACK, J. As hidrelétricas e o aquecimento global. Política energética. Ciência hoje. V. 41. N.245. 2008.

MACEDO, Valéria (2003). Estrada, Mineração e Barragem. Disponível em http://www.socioambiental.org

SANTOS, S; NACKE, A. Povos indígenas e desenvolvimento na Amazônia. Revista Brasileira de Ciências Sociais. 71 -84. 1988.

SCHWADE, E. Hidrelétrica de Balbina contra índios e lavradores. Revista de Cultura Vozes 79. 39-43, 1985.

SERÁFICO, J; SERÁFICO, M. A Zona Franca de Manaus e o capitalismo no Brasil. ESTUD. AV. VOL.19 NO.54 SÃo PAULO MAY/AUG. 2005.

SILVA FILHO, Eduardo Gomes da. No rastro da tragédia: projetos desenvolvimentistas na terra indígena Waimiri-Atroari. Tessituras, Pelotas, v. 2, n. 2, p. 293-314, jul./dez. 2014.

SILVA, Marilene Corrêa. As metamorfoses da Amazônia. Manaus, Ed. da UFAM, 2000.

THOMÉ, J, L. Hidrelétrica de Balbina: Um fato consumado. Dissertação de mestrado apresentada ao programa de pós- graduação em Ciências sociais da Universidade Federal de Santa Catarina. Florianópolis, 1993.

VEIGA, Sandra Mayrink; FONSECA, Isaque. Cooperativismo: uma revolução pacífica em ação. Rio de janeiro: DP\&A: Fase, 2002.

YIN, ROBERT K. Estudo de caso: planejamento e métodos. Porto Alegre: Bookman, 2015. 